\title{
Improving soil properties and productivity of crop-pasture rotation in arid steppe of the Southern Urals
}

\author{
Yakhiya Kaipov*, Rifkat Akchurin, Rustam Kirayev, and Asiya Nizaeva \\ Ufa Federal Research Center of the Russian Academy of Sciences, Bashkir Research Institute of \\ Agriculture, Ufa, Russia
}

\begin{abstract}
Field experiments were conducted in the arid steppe zone of the Southern Urals, in the Republic of Bashkortostan of the Russian Federation. The soil is common chernozem. The precipitation during the growing season (May-September) is $166 \mathrm{~mm}$. The experimental crop rotation consisted of 7 fields: 4 with perennial herbs (a mixture of Bromus inermis and Medicago varia), 3 with annual crops. The study analysed soil properties and carrying capacity in perennial grass rotation, conventional and reduced tillage. During the crop-pasture rotation, the humus content in the soil changes insignificantly depending on the tillage, being within 7.6$8.0 \%$. Perennial grasses loosened the soil, positively affecting moisture accumulation under crop rotation by the beginning of the pre-sowing period. The arable layer of common chernozem in the reduced tillage had a density of $1.05 \mathrm{~g} / \mathrm{cm}^{3}$, less than $0.06 \mathrm{~g} / \mathrm{cm}^{3}$ in conventional cultivation. Fertilizer application increased yields at $0.49-0.51 \mathrm{t} / \mathrm{ha}$ of feed units. Reduced tillage resulted in higher feed units by $0.06-0.08$ tons per 1 ha. Crop-pasture rotation implementation and development ensures bioclimatically-determined yields of fodder crops and maintains soil fertility at an optimal level.
\end{abstract}

\section{Introduction}

Continued fodder production involves a reasonable combination of field and meadow components. Crop-pasture rotation in the arid steppe zone of the Southern Urals is very limited due to a sharp decrease in the productivity of natural hayfields and pastures. Frequent droughts in recent decades have been intensifying this negative process. Thus, there was an average of $166 \mathrm{~mm}$ precipitation during the growing season of forage crops (May-September) in the Trans-Ural steppe of the Republic of Bashkortostan in 2006-2015, or $14 \%$ less than the average annual values. The number of highly arid years with growing season precipitation amounting to $25-70 \%$ of the norm has increased. Such years for the specified period of observations were repeated 4 times. Accordingly, fodder harvest from natural lands has decreased. In recent years, the zone's productivity of natural hayfields and pastures has been only $0.5-0.7$ tons of hay per 1 ha. In the arable fodder cropping based on

${ }^{*}$ Corresponding author: sci_secr_bniish@bk.ru 
more fertile soils, the fodder harvesting remained 5-6 times higher than on natural lands. However, the increasing aridity limits the potential of field-cultivated land. The main challenge is to make full use of scarce precipitation. The present study relies on the working hypothesis that crop-pasture rotation with the soil-improving impact of perennial grasses can solve this problem by the maximum use of atmospheric and soil moisture and higher carrying capacity of arable land. The steppe zone's improved physical properties and soil hydrological regime is a growing concern worldwide $[1,2]$.

This paper aimed to examine the effect of crop-pasture rotation on the soil humus content, agrophysical properties, and the carrying capacity of arable land. The study set out to accomplish the following objectives: conducting a field experiment, studying changes in the soil humus content, density and moisture under the influence of crops and their cultivation technology, taking into account the yielding capacity of fodder crops.

\section{Materials and methods}

Field experiments were conducted in the Baimak scientific division of the Bashkir Agricultural Research Institute in 2011-2015. The experimental field is located in the eastern steppe foothills of the Southern Urals. Relief

Table 1. Recommended fertilizer rates for crop-pasture rotation.

\begin{tabular}{|c|c|c|}
\hline $\begin{array}{c}\text { Field } \\
\text { No. }\end{array}$ & Crops & $\begin{array}{c}\text { Fertilizer rates, kg of } \\
\text { active substance per 1 ha }\end{array}$ \\
\hline 1 & Sudangrass for fodder + perennial herbs & $\mathrm{N}_{40} \mathrm{P}_{60} \mathrm{~K}_{20}$ \\
\hline 2 & 2-year-old perennial grasses for hay & $\mathrm{P}_{45} \mathrm{~K}_{45}$ \\
\hline 3 & 3-year-old perennial grasses & $\mathrm{P}_{45} \mathrm{~K}_{45}$ \\
\hline 4 & 4-year-old perennial grasses & $\mathrm{N}_{60} \mathrm{P}_{30}$ \\
\hline 5 & 5-year-old perennial grasses & $\mathrm{N}_{60} \mathrm{P}_{30}$ \\
\hline 6 & $\begin{array}{c}\text { Barley for grain } \\
\text { mass }\end{array}$ & $\mathrm{N}_{50} \mathrm{P}_{60} \mathrm{~K}_{20}$ \\
\hline 7 & Rapeseed for green fodder & $\mathrm{N}_{45} \mathrm{P}_{45}$ \\
\hline
\end{tabular}

plain, the soil is common medium depth heavy loamy chernozem. The climate is sharp continental, arid. The annual precipitation is $330 \mathrm{~mm}$, of which $192 \mathrm{~mm}$ is during the growing season (May-September). An experimental crop-pasture rotation was based on the following design: 1-4 fields - perennial grasses; 5-barley for grain; 6-rapeseed for green fodder; 7-Sudanese grass for fodder + perennial grasses. The effect of tillage systems in crop rotation was studied: without fertilizers, with fertilizers; according to the scheme:

1) conventional tillage;

2) reduced cultivation.

The soil in conventional tillage was loosened to a depth of $28-30 \mathrm{~cm}$ for perennial grasses and 20-22 cm for barley and rapeseed. In reduced cultivation, the tillage depth was reduced to $20-22 \mathrm{~cm}$ for perennial grasses and barley, $12-14 \mathrm{~cm}$ for rapeseed. The species composition of perennial grasses consisted of awnless brome (Bromus inermis) with variegated alfalfa (Medicago varia). Mineral fertilizers were applied in addition to fertilizers at rates recommended for the studied area (Table 1).

Field experiments were carried out according to the method of B.A. Dospekhov (1985), laboratory studies according to generally accepted methods. Statistical processing of the 
long-term field experiment data was performed according to the method of V.I. Koronevsky [3].

\section{The results and discussion}

The most important agrochemical and agrophysical properties of the soil depend on the humus content. The factors used in the experiment had a certain impact on this indicator (Table 2).

Table 2. Changes in the humus content in the arable layer $(0-30 \mathrm{~cm})$ of common chernozem under the effect of fertilizers and tillage during crop-pasture rotation.

\begin{tabular}{|c|c|c|c|c|c|}
\hline \multirow[t]{2}{*}{ Soil tillage } & \multirow[t]{2}{*}{ Fertilizer } & \multicolumn{2}{|c|}{$\begin{array}{l}\text { The humus analysis } \\
\text { time }\end{array}$} & \multirow{2}{*}{$\begin{array}{l}\text { Change } \\
\text { towards the } \\
\text { end of the } \\
\text { rotation }\end{array}$} & \multirow{2}{*}{$\begin{array}{l}\text { Difference by } \\
\text { tillage } \\
\text { systems, by } 2015\end{array}$} \\
\hline & & 2008 & 2015 & & \\
\hline \multirow[t]{2}{*}{$\begin{array}{l}\text { Conventio } \\
\text { nal }\end{array}$} & $\begin{array}{l}\text { Without } \\
\text { fertilizers }\end{array}$ & 7.63 & 7.58 & -0.05 & - \\
\hline & With fertilizer & 7.68 & 7.68 & 0 & - \\
\hline \multirow[t]{3}{*}{ Reduced } & $\begin{array}{l}\text { Without } \\
\text { fertilizers }\end{array}$ & 7.65 & 7.62 & -0.03 & $+0.04(0.5 \%)^{*}$ \\
\hline & With fertilizer & $7 \mathrm{uk} 5.75$ & 8.00 & +0.05 & $+0.32(4 \%)$ \\
\hline & & & $\mathrm{LSD}_{05}=$ & 0.03 & 0.09 \\
\hline
\end{tabular}

* in parentheses - the change value in relative percentages

By the end of the experimental crop-pasture rotation in the conventional cultivation without fertilizers, the humus content in the arable layer slightly decreased, from $7.63 \%$ of the initial to $7.58 \%$ in the final state. The change is 0.03 absolute percent, which is statistically proven. The humus content at conventional cultivation with applied mineral fertilizers did not change during the compared period, remaining equal to $7.68 \%$. The humus content at reduced tillage without fertilizers decreased by $0.03 \%$. It is insignificant and shows only a trend. While reduced cultivation with fertilizers increased the humus content from 7.75 to $8.00 \%$, which is clearly provable and indicates a natural increase in the studied indicator with the above factors. Comparing the effect of the tillage systems in the final term (2015) provides a more visual representation. The humus content at reduced cultivation without fertilizers turned out to be the same as in conventional tillage. A small increase of $0.04 \%$ at reduced tillage is not statistically proven. The humus content was significantly higher, by $0.32 \%$, at reduced cultivation with fertilizers relative to conventional tillage. Thus, in the conditions of natural plant nutrition, conventional cultivation decreases the humus content insignificantly. Reduced cultivation provides the negligible humus content decline, estimated as a trend. The soil humus balance improves during crop-pasture rotation with applied fertilizers. Conventional tillage stabilizes the humus content at the initial stage; reduced cultivation increases it significantly. The presence of perennial grasses in the rotation, providing a large amount of organic residues, had a positive effect on the humus reproduction in the experimental crop rotation. The important role of such crop rotations in reproducing soil organic carbon (SOC) is indicated by K.L. Page, Y.P. Dang, R.C. Dalal (2020) [4]; improved agrochemical, agrophysical properties and soil fertility is shown by V.G. Loshakov (2002), V.G. Grebennikov, I.A. Shipilov (2012) [5, 6]. Including perennial grasses in crop rotations can improve the balance of soil organic matter in the arid conditions of Western Siberia [7], the Central Black-soil region of Russia [8].

The most effective indicator that affects the precipitation uptake rate is the soil density. In our experiment, crop rotation plants had different impacts on this indicator (Table 3 ). In 
all the years of analysis, the density of the arable soil layer under perennial grasses was lower than under annual barley, ranging from 0.99 to $1.05 \mathrm{~g} / \mathrm{cm}^{3}$. For all years the average soil density under perennial grasses was $1.02 \mathrm{~g} / \mathrm{cm}^{3}$. The soil density under barley over these years ranged from 1.05 to $1.15 \mathrm{~g} / \mathrm{cm}^{3}$, with an annual average of $1.09 \mathrm{~g} / \mathrm{cm}^{3}$. The average density of the arable soil layer under barley over the years was $0.07 \mathrm{~g} / \mathrm{cm}^{3}$ higher than under perennial grasses. The relative difference is $6.9 \%$, the regularity is confirmed by statistical processing. Despite significant fluctuations, the average density of the arable soil layer under both crops of crop rotation remained within the lower limit of the optimal indicators for arable chernozem soils of the natural-climatic research zone. The lower soil density under perennial grasses had a favourable effect on reducing this indicator on average for the crop rotation since the predominant share of perennial grasses of $57 \%$.

Table 3. The impact of crop-pasture rotation on soil density in the arable layer for 2011-2015.

\begin{tabular}{|l|l|l|l|l|l|l|l|l|}
\hline Crop & \multirow{9}{|l|}{$\begin{array}{l}\text { Soil } \\
\text { rotation } \\
\text { plant }\end{array}$} & $\begin{array}{l}\text { layer, } \\
\text { cm }\end{array}$ & 2011 & 2012 & 2014 & 2015 & Average & \multicolumn{2}{|l|}{ Difference } & $\%$ \\
\hline $\begin{array}{l}\text { Perennial } \\
\text { herbs for } \\
\text { hay }\end{array}$ & $0-30$ & 0.99 & 1.05 & 1.02 & 1.05 & 1.02 & - & - \\
\hline $\begin{array}{l}\text { Barley for } \\
\text { grain }\end{array}$ & $0-30$ & 1.15 & 1.13 & 1.05 & 1.08 & 1.09 & +0.07 & +6.9 \\
\hline LSD 05 & & 0.05 & 0.06 & 0.03 & 0.03 & - & 0.04 & - \\
\hline
\end{tabular}

Loose soil consistency in the crop rotation contributed to better infiltration of rain and snow precipitation, increased spring reserves of productive moisture at the beginning of the fodder crops' growing season (Table 4).

Table 4. Spring pre-sowing reserves of productive moisture in the meter layer in crop-pasture rotations, depending on the density of the arable layer. Average for 2011-2015.

\begin{tabular}{|l|l|l|l|l|l|l|l|}
\hline $\begin{array}{c}\text { Crop-pasture } \\
\text { rotation }\end{array}$ & $\begin{array}{l}\text { Soil } \\
\text { density, } \\
\mathrm{g} / \mathrm{cm}^{3}\end{array}$ & $\begin{array}{l}\text { Productive } \\
\text { moisture, } \\
\mathrm{mm}\end{array}$ & $\begin{array}{l}\text { Grain crop } \\
\text { rotation* }\end{array}$ & $\begin{array}{l}\text { Soil } \\
\text { density, } \\
\mathrm{g} / \mathrm{cm}^{3}\end{array}$ & $\begin{array}{l}\text { Productive } \\
\text { moisture, } \\
\mathrm{mm}\end{array}$ & $\begin{array}{l}\text { lhe } \\
\text { difference in } \\
\text { the content of } \\
\text { productive } \\
\text { moisture }\end{array}$ \\
\cline { 5 - 8 } & & 138 & $\begin{array}{l}\text { Annual } \\
\text { crops }\end{array}$ & 1.17 & 110 & +28 & $\%$ \\
\hline $\begin{array}{l}\text { Annual crops } \\
\text { grasses }\end{array}$ & 1.09 & 143 & & & & +33 & 30 \\
\hline
\end{tabular}

* - for comparison, a grain crop rotation of a neighboring experimental field was used. The relief and soil were similar to the crop-pasture rotation.

Having a less dense consistency, the meter-long soil layer of the crop-pasture rotation accumulated a relatively large amount of productive moisture by the spring pre-sowing period, 138-143 mm. The more compacted soil of the grain crop rotation, having no perennial grasses, stored $110 \mathrm{~mm}$ of moisture, $25-30 \%$ less than in the crop-pasture rotation. Thus, the crop-pasture rotation accumulates higher reserves of productive moisture by the pre-sowing period than the grain crop rotation. The factor that increases the moisture reserves in the crop-pasture rotation is the favourable impact of perennial grasses on the humus content and the soil consistency density. Studies in Europe also emphasize the improvement of all important soil properties and functions as the organic carbon contained in it increases $[9,10]$. Turusov V. I. and co-authors (2017) report on better water-physical properties of typical and common chernozems in field crop rotations with two fields of 
perennial grasses (esparcet) [11]. J. W. Erisman (2016), B. R. De Haas et al. (2019) claim that meadow farming systems (as well as perennial grass planting) reduce the risk of climate change consequences by better water absorption, improved soil structure and reduced erosion $[12,13]$.

Tillage systems affected the soil density in the experimental crop rotation additionally. On average, in 2011-2015, the arable layer $(0-30 \mathrm{~cm})$ of common chernozem in the reduced cultivation system had a lower density than in conventional tillage. The corresponding indicators were 1.05 and $1.11 \mathrm{~g} / \mathrm{cm}^{3}$ (Table 5).

However, in some years, reduced cultivation resulted in a denser soil consistency compared to conventional tillage. The densest soil at reduced cultivation was in the growing season of 2014. The reason was the changed weather conditions. The previous autumn (2013) was arid, and by the time of the main tillage, reduced cultivation did not loosen the excessively dry and dense soil sufficiently.

The dense soil poorly absorbed the moisture of autumn-winter precipitation. During the growing season of 2014, the moisture reserves in the soil remained lower than under the conventional tillage system. The same dry autumn preceded

Table 5. The impact of tillage processing systems on the density of the arable layer $(0-30 \mathrm{~cm})$ of common chernozem, depending on the weather conditions

\begin{tabular}{|l|c|c|c|c|l|l|l|}
\hline \multirow{2}{*}{$\begin{array}{l}\text { Tillage } \\
\text { system }\end{array}$} & \multicolumn{3}{|c|}{ Years, their climatic characteristics } & \multicolumn{2}{l|}{$\begin{array}{l}\text { Averag } \\
\mathrm{e}\end{array}$} & \multicolumn{2}{c|}{ Difference } \\
\cline { 2 - 7 } $\begin{array}{l}\text { Conventi } \\
\text { onal }\end{array}$ & 2011 & 2012 & 2014 & 2015 & $\mathrm{~g} / \mathrm{cm}^{3}$ & $\%$ \\
\hline Reduced & 0.15 & 1.13 & 1.11 & 1.04 & 1.11 & - & - \\
\hline & $\begin{array}{c}\text { Mid-arid } \\
\text { autumn, } \\
\text { snowy } \\
\text { winter, }\end{array}$ & $\begin{array}{c}\text { Wet } \\
\text { autumn, } \\
\text { dry } \\
\text { winter, } \\
\text { moderate } \\
\text { spring }\end{array}$ & $\begin{array}{c}\text { Dry autumn, } \\
\text { snowy } \\
\text { winter, } \\
\text { acutely dry } \\
\text { spring }\end{array}$ & $\begin{array}{c}\text { Wet autumn, } \\
\text { dry winter, } \\
\text { moderate } \\
\text { spring }\end{array}$ & 1.05 & -0.06 & 5.4 \\
\hline & & & & LSD & & & \\
\hline
\end{tabular}

the growing season of 2015 , but the spring with moderate precipitation (before sowing) softened the soil, and the difference in its density by tillage systems decreased. Despite the small differences in soil density caused by the weather conditions, the average annual moisture supply by cultivation methods remained the same. The average annual productivity of crop-pasture rotation for 2011-2015 ranged from 1.88 to $2.38 \mathrm{t} / \mathrm{ha}$ of feed units (f.un.), depending on the soil treatment and fertilizer systems (Table 6). Annual crops showed higher carrying capacity. Rapeseed productivity without fertilizers was $2.53 \mathrm{t} / \mathrm{ha}$ of feed units and $3.39 \mathrm{t} / \mathrm{ha}$ of f.un. with applied fertilizers. Sudangrass productivity was 2.14 and $2.84 \mathrm{t} / \mathrm{ha}$, respectively. The yield gains from fertilizers in the same cultivation systems averaged $0.49 \ldots 0.51 \mathrm{t} / \mathrm{ha}$. There was an additional $5 \mathrm{~kg}$ of feed units per $1 \mathrm{~kg}$ of the active substance of fertilizers. Approximately the same productivity was recorded by applying fertilizer rates close to our experience (Table 1) by D.V. Mitrofanov and Yu.V. Kaftan (2016) in the Orenburg region of Russia [14]. This study was conducted in the steppe zone of the Southern Urals, thereby confirming our results. The average feed unit gain at the reduced tillage system without fertilizers was $0.06 \mathrm{t} / \mathrm{ha}$ higher than conventional cultivation. When applying fertilizers, the advantage of reduced tillage over conventional cultivation was higher and amounted to 0.08 tons of additional products per 1 ha. The achieved carrying capacity of crop-pasture rotation in our field experiment approaches the calculated value for the conditions of the arid steppe of the Southern Urals. Therefore, the croppasture rotation introduction and development with $57 \%$ of perennial grasses and $43 \%$ of annual crops provide bioclimatically-determined yields of fodder crops and preserve the 
main agrochemical and agrophysical properties of the soil at the optimal level for the research area. Scholars of the Samara Agricultural Research Institute conducted many-year studies in conditions similar to those examined in this paper, and their findings were close to the results of this analysis [15]. A.G. Bondarev and I.V. Kuznetsov (1999, 2007) suggested measures to maintain soil fertility at an optimal level, including an increase in the share of perennial grasses in crop rotation to $30 \%$, the annual use of up to $10-12 \mathrm{t} / \mathrm{ha}$ of organic fertilizers, the replacement of deep treatments with surface cultivation, the use of a controlled Table 6 .

Table 6. Average annual productivity of crop-pasture rotation depending on the tillage system and fertilizers applied for 2011-2015.

\begin{tabular}{|c|c|c|c|c|c|c|c|}
\hline \multirow[t]{2}{*}{$\begin{array}{l}\text { Field } \\
\text { No. }\end{array}$} & \multirow[t]{2}{*}{ Crops } & \multirow[t]{2}{*}{ Fertilizer } & \multicolumn{2}{|c|}{$\begin{array}{l}\text { Feed units } \\
\text { harvest, } \\
\text { t/ha }\end{array}$} & \multicolumn{2}{|c|}{$\begin{array}{l}\text { The effect of } \\
\text { fertilizers }\end{array}$} & \multirow{2}{*}{$\begin{array}{c}\text { The } \\
\text { difference at } \\
\text { reduced } \\
\text { cultivation } \\
\text { RT-CT }\end{array}$} \\
\hline & & & $\mathrm{CT}^{*}$ & RT* & CT & RT & \\
\hline \multirow[t]{2}{*}{1} & \multirow{2}{*}{$\begin{array}{c}\text { Sudangrass }+ \\
\text { perennial } \\
\text { grasses }\end{array}$} & $\begin{array}{l}\text { Without } \\
\text { fertilizers }\end{array}$ & 2.34 & 2.14 & - & - & -0.20 \\
\hline & & $\begin{array}{c}\text { With } \\
\text { fertilizer }\end{array}$ & 2.84 & 2.65 & +0.50 & +0.51 & -0.19 \\
\hline \multirow[t]{2}{*}{$2-5$} & \multirow{2}{*}{$\begin{array}{l}\text { 2-5-year-old } \\
\text { perennial } \\
\text { grasses }\end{array}$} & $\begin{array}{l}\text { Without } \\
\text { fertilizers }\end{array}$ & 1.68 & 1.72 & - & - & +0.04 \\
\hline & & $\begin{array}{c}\text { With } \\
\text { fertilizer }\end{array}$ & 2.10 & 2.16 & +0.42 & +0.44 & +0.06 \\
\hline \multirow[t]{2}{*}{6} & \multirow[t]{2}{*}{ Barley for grain } & $\begin{array}{l}\text { Without } \\
\text { fertilizers }\end{array}$ & 1.37 & 1.50 & - & - & +0.13 \\
\hline & & $\begin{array}{c}\text { With } \\
\text { fertilizer }\end{array}$ & 1.63 & 1.77 & +0.26 & +0.27 & +0.14 \\
\hline \multirow[t]{2}{*}{7} & \multirow[t]{2}{*}{$\begin{array}{l}\text { Rapeseed for } \\
\text { green mass }\end{array}$} & $\begin{array}{l}\text { Without } \\
\text { fertilizers }\end{array}$ & 2.53 & 2.87 & - & - & +0.34 \\
\hline & & $\begin{array}{c}\text { With } \\
\text { fertilizer }\end{array}$ & 3.02 & 3.39 & +0.49 & +0.52 & +0.37 \\
\hline & \multirow[t]{2}{*}{$\begin{array}{l}\text { Average for } \\
\text { crop rotation }\end{array}$} & $\begin{array}{l}\text { Without } \\
\text { fertilizers }\end{array}$ & 1.88 & 1.94 & - & - & +0.06 \\
\hline & & $\begin{array}{c}\text { With } \\
\text { fertilizer }\end{array}$ & 2.30 & 2.38 & +0.42 & +0.44 & +0.08 \\
\hline & & $\begin{array}{l}\text { Without } \\
\text { fertilizers }\end{array}$ & & $\mathrm{LSD}_{05}$ & 0.23 & 0.25 & 0.06 \\
\hline & & $\begin{array}{c}\text { With } \\
\text { fertilizer }\end{array}$ & & $\mathrm{LSD}_{05}$ & - & - & 0.07 \\
\hline
\end{tabular}

* CT - conventional tillage; RT - reduced tillage

traffic farming [16]. These suggestions are consistent with the above results of the present research.

\section{Conclusion}

1. During the crop-pasture rotation, the humus content in the arable layer of common chernozem changes insignificantly and depends on soil cultivation. The humus content decreases slightly from $7.63 \%$ at the beginning to $7.58 \%$ at the end under conventional cultivation without fertilizers. The humus content slows down at reduced cultivation without fertilizers, but it is an insignificant trend. Conventional tillage with fertilizers stabilizes the humus content at the initial stage; reduced cultivation increases it significantly. 
2. The average soil density for all years under perennial grasses was $1.02 \mathrm{~g} / \mathrm{cm}^{3}$, which is $0.07 \mathrm{~g} / \mathrm{cm}^{3}$ less than under annual crops of crop-pasture rotation.

3. The crop-pasture rotation accumulates higher reserves of productive moisture by the presowing period than the grain crop rotation. The corresponding indicators are 138 and 110 $\mathrm{mm}$. The factor that increases the moisture reserves in the crop-pasture rotation is the favourable impact of perennial grasses on the humus content and the soil consistency density.

4. The arable layer $(0-30 \mathrm{~cm})$ of common chernozem in the reduced tillage system has an average density of $1.05 \mathrm{~g} / \mathrm{cm}^{3}$ for many years, less than $0.06 \mathrm{~g} / \mathrm{cm}^{3}$ in conventional cultivation. In some arid years, reduced cultivation results in a denser soil consistency compared to conventional tillage. Despite the small differences in soil density caused by the weather conditions, the average annual moisture supply by cultivation methods remains the same.

5. The average annual productivity of crop-pasture rotation in the conditions of increasing aridity in the Southern-Ural steppe ranges from 1.88 to $2.38 \mathrm{t} / \mathrm{ha}$ of feed units, depending on the tillage systems and fertilizers. The yield gains from fertilizers in the same cultivation systems averaged $0.49 \ldots 0.51 \mathrm{t} / \mathrm{ha}$. There was an additional $5 \mathrm{~kg}$ of feed units per $1 \mathrm{~kg}$ of the active substance of fertilizers. Reduced tillage ensures feed units harvest from 1 ha by $0.06-$ 0.08 tons more than conventional cultivation. The introduction and development of a feed crop rotation with the share of perennial grasses $57 \%$ and annual crops $43 \%$ allow us to obtain a bioclimatically determined yield of feed crops and preserve the main agrochemical and agrophysical properties of the soil at the optimal level for the research area.

\section{Acknowledgements}

The study was carried out in the Seed-Breeding Center for Forage Crops of UFRC RAS" (project No. 075-15-2021-549).

\section{References}

1. B. Boincean, A. Kassam, G. Basch, D. Reicosky, E. Gonzalez, T. Reynolds, M. Ilusca, M. Cebotari, Gr. Rusnac, Vadim Cuzeac, L. Bulat, D. Pasat, S. Stadnic, S. Gavrilas, and Boaghii, AIMS Agr. and Food J. 1(4) (2016)

2. Dhanya Praveen et al., AIMS Agr. and Food J. 1(3) (2016)

3. V.I. Koronevskii, Farming, 11 (1985) (in Russian)

4. K.L. Page, Y.P. Dang, R.C. Dalal, Sust. Food Syst. J. 4, 31 (2020)

5. V.G. Loshakov, Bulletin of the Temiriazev State Agricultural Academy, 1 (2002) URL: https://ciberleninka.ru /article/n/itogi-issledovaniy-po-sevooborotam (in Russian)

6. V.G. Grebennikov, I.A. Shipilov, Agricultural Journal 1 (2012) URL: https://ciberleninka.ru/article/n/mnogoletnietravy-v-lugopastbicnyh-sevooborotah (in Russian)

7. A.P. Drobyshev, M.I. Maltsev, V.P. Opeshko, V.I. Usenko, E.R. Shukis, Bulletin of the Altai State Agrarian University, 12 (2017) (in Russian) 
8. A.V. Dedov, M.A. Nesmeianova, Agrochemical Bulletin 4 (2012) (in Russian)

9. E.J. González-Sánchez, A. Kassam, G. Basch, B. Streit, A. Holgado-Cabrera, P. Triviño-Tarradas, AIMS Agr. and Food J. 1(4) (2016)

10. Humberto Blanco, Sabrina J. Ruis, Geoderma J. 326 (2016)

11. V.I. Turusov, A.M. Novochikhin, O.A. Bogatykh, E.G. Bocharnikova, Achievements of Science and Technology of Agriculture, 31, 10, 27-31 (2017) (in Russian)

12. J.W. Erisman, N. Eekeren, J. Wit, C. Koopmans, W. Cuijpers, N. Oerlemans, B.J. Koks. AIMS Agr. and Food J, 1(2) (2016)

13. B.R. de Haas, N.J. Hoekstra, J.R. van der Schoot, Eric J.W. Visser, H. Kroon and Nick van Eekeren, AIMS Agr. and Food J. 4(3) (2019)

14. D.V. Mitrofanov, Iu.V. Kaftan, Proceedings of the Orenburg State University 4 (60) (2016) (in Russian)

15. Bioclimatic productivity potential of spring durum wheat in the Middle Volga region, Agricultural news, (2017) (in Russian) URL: https://agrovesti.net/viraschivanie_zernovich/proizvodstvo_visokokachestvennogo_zer na_yarovoy_tverdoy_pshenitsi_v_srednem_povolzhe.html?auid=699

16. T.A. Trofimova, S.I. Korzhov, V.A. Gulevskii, V.N. Obraztsov, Soil Science J. 9, (2018) (in Russian) 